\title{
Burkitt's lymphoma mimicking EBV disease as first sign of vertical HIV infection in an adolescent
}

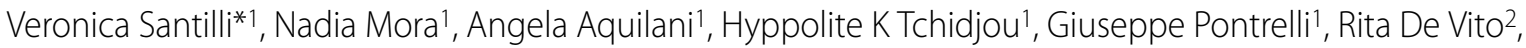 \\ Alessandra Lombardi³, Stefania Bernardi ${ }^{1}$ and Paolo Palma
}

\begin{abstract}
Burkitt's Lymphoma (BL) rarely represents the first clinical manifestation of vertical HIV infection in adolescent in Western Europe. We report the case of a 17 year-old boy with two week history of fever and enlarged cervical lymph nodes firstly misdiagnosed as EBV infection, subsequently diagnosed as Burkitt's Lymphoma and vertical HIV infection.
\end{abstract}

\section{Background}

Human immunodeficiency virus (HIV)-infected children are at increased risk of developing cancer, particularly in the later stages of acquired immune deficiency syndrome (AIDS) [1]. The introduction of efficacious regimens of antiretroviral treatment has resulted in a substantial and dramatic decrease in AIDS-related opportunistic infections and cancers [1]. However, despite this progress, recent data show as HIV infection itself represents a major risk factor for developing cancers and non-Hodgkin's Lymphoma (NHL) which remains the most frequent malignancy in subjects with AIDS [2].

\section{Case Report}

A 17 years-old boy was admitted with a short history of fever, tonsillitis and monolateral enlarged cervical lymph nodes non responsive to antibiotic therapy with Clarithromycin. Familiar history showed mother's death for lymphoma and remote history was silent with normal growth and neurocognitive development and a single episode of bronchopneumonia at the age of 4 years. Initial clinical examination revealed good general condition except for the enlargement of right side cervical lymph node $3 \mathrm{~cm}$ in diameter hard and painful, hepatosplenomegaly, pharyngeal hyperemia. No other alterations were found, even through neurological examination. Biological tests disclosed the following values: haemoglobin $11.9 \mathrm{~g} /$ dl; leucocytes $5.78 \times 10^{\wedge} 3 / \mathrm{uL}$ with $39,5 \%$ lymphocytes and 50,7\% neutrophils; platelets $91 \times 10^{\wedge} 3 / \mathrm{uL}$; sedimen-

* Correspondence: veronica.santilli@hotmail.it

1 DPUO, University Department of Pediatrics-Children's Hospital Bambino Gesù, Rome, Italy

Full list of author information is available at the end of the article tation rate, $77 \mathrm{~mm} / \mathrm{h}$; CRP $1.36 \mathrm{mg} / \mathrm{dl} ; \mathrm{LDH} 523 \mathrm{UI} / \mathrm{L}$; GOT 57 UI/L; GPT 41 UI/L [Table 1].

On the basis of clinical and laboratory signs we performed microbiological tests to rule out Epstein-Barr virus (EBV) infection, our first diagnostic suspect. Serology test for EBV showed the presence of anti-EBNA and VCA IgG whereas IgM anti-VCA resulted negative. In parallel, polymerase chain reaction $(\mathrm{PCR})$ detected the presence of $20.000 \mathrm{EBV}$ blood copies/ml. ELISA test for hepatitis A (HAV), hepatitis C (HCV), hepatitis B (HBV), cytomegalovirus (CMV) resulted IgM and IgG negative. Cervical ultrasound showed enlarged right side cervical lymph nodes $4,5 \mathrm{~cm}$ in diameter with a loss of hilar echogenic central and hilar architecture, presence of intranodal necrosis, calcification and high peripheral and central perfusion. There were also multiple nodes in the left side of about $1 \mathrm{~cm}$ in diameter. Abdominal ultrasound showed hepatosplenomegaly and modest increase of hepatic hilus and retroperitoneal lymph nodes. Mycobacterial infection was excluded by Interferon gamma release assay.

Due to the persistence of tonsillopharyngitis and lymphoadenopathy over two weeks of follow-up, the patient underwent open biopsy showing a malignant population of round monomorphic B cells, interspersed with macrophages forming the "stars" in the "starry sky" histology pattern typical of the Burkitt's Lymphoma (BL) [Fig 1]. The malignant cells were strongly positive for CD20, CD79a and CD10 [Fig 2, 3] and T-lymphocyte markers (CD3 and TdT) were negative. Detection of EBV RNA in corresponding tumor tissues was carried out using in situ hybridization. In view of the hypergammaglobulinemia 
Table 1: Patient's haematological data on admission and during follow-up.

\begin{tabular}{|c|c|c|c|c|c|}
\hline & On admission & $\begin{array}{c}\text { After } 5 \text { months } \\
\text { of } \\
\text { Chemotherapy } \\
\text { and HAART }\end{array}$ & $\begin{array}{l}\text { After } 10 \text { months } \\
\text { of follow up }\end{array}$ & $\begin{array}{l}\text { After } 2 \text { years of } \\
\text { follow up }\end{array}$ & $\begin{array}{l}\text { After } 3 \text { years of } \\
\text { follow up }\end{array}$ \\
\hline $\mathrm{Hb}(\mathrm{g} / \mathrm{dl})$ & 11.9 & 11.6 & 14.6 & 15.5 & 16.1 \\
\hline $\mathrm{RBC}\left(\times 10^{\wedge} 6 / \mathrm{ul}\right)$ & 4.38 & 3.87 & 4.57 & 4.91 & 5.07 \\
\hline WBC $\left(\times 10^{\wedge} 3 / \mathrm{ul}\right)$ & 5.78 & 5.21 & 6.82 & 8.36 & 8.25 \\
\hline Neu $(\times 10 \wedge 3 / u l)$ & 2.93 & 2.63 & 3.41 & 5.01 & 5.10 \\
\hline $\operatorname{Lym}(\times 10 \wedge 3 / u l)$ & 2.20 & 1.94 & 2.82 & 2.51 & 2.46 \\
\hline PLT $(\times 10 \wedge 3 / \mathrm{ul})$ & 91 & 177 & 230 & 221 & 218 \\
\hline CRP mg/dl & 1.36 & 0.25 & 0.20 & $<0.05$ & 0.47 \\
\hline LDH (UI/L) & 523 & 441 & 354 & 248 & 286 \\
\hline GOT (UI/L) & 57 & 16 & 22 & 18 & 18 \\
\hline GPT (UI/L) & 41 & 13 & 12 & 12 & 12 \\
\hline $\lg A(m g / d l)$ & 608 & 288 & 284 & 320 & 339 \\
\hline $\lg G$ (mg/dl) & 2306 & 707 & 1256 & 1025 & 933 \\
\hline $\lg M(\mathrm{mg} / \mathrm{dl})$ & 440 & 122 & 250 & 145 & 134 \\
\hline $\begin{array}{l}\text { HIV Viral Load } \\
\text { (copies/ml) }\end{array}$ & 118.000 & 320 & $<50$ & $<50$ & $<50$ \\
\hline $\begin{array}{l}\text { CD4+\%/abs } \\
\text { (cell/ul) }\end{array}$ & $5 \% / 114$ & $9 \% / 174$ & $11 \% / 298$ & $21 \% / 527$ & $25 \% / 603$ \\
\hline $\begin{array}{c}\text { EBV RNA blood/ } \\
\text { plasma } \\
\text { (copies/ml) }\end{array}$ & $0 / 20.000$ & $0 / 43.000$ & $113.000 / 5.400$ & $0 / 0$ & $0 / 0$ \\
\hline
\end{tabular}

(IgA $608 \mathrm{mg} / \mathrm{dl}$, IgG $2306 \mathrm{mg} / \mathrm{dl}$ and IgM $440 \mathrm{mg} / \mathrm{dl}$ ) associated with severe immunodeficiency (CD4 count $\left.114 / \mathrm{mm}^{3}-5 \%\right)$ HIV infection was suspected and confirmed by standard ELISA serology test and quantitative PCR (HIV viral load 118.000 copies/ml). Thus, diagnosis of HIV-related BL was established and subsequently confirmed in his mother by the acquisition of her medical history. To investigate tumour staging Total Body CT scan was performed confirming the presence of enlarged cervical and abdominal lymph nodes with typical patterns of malignancy. Bone scintigraphy and bone marrow biopsy were negative. Brain MRI, lumbar puncture and cerebrospinal fluid cytology showed any involvement of central nervous system (CNS). However due to the presence of third branch trigeminal nerve palsy CNS involvement was considered. Staging classification was Ann Arbor Stage IV. 


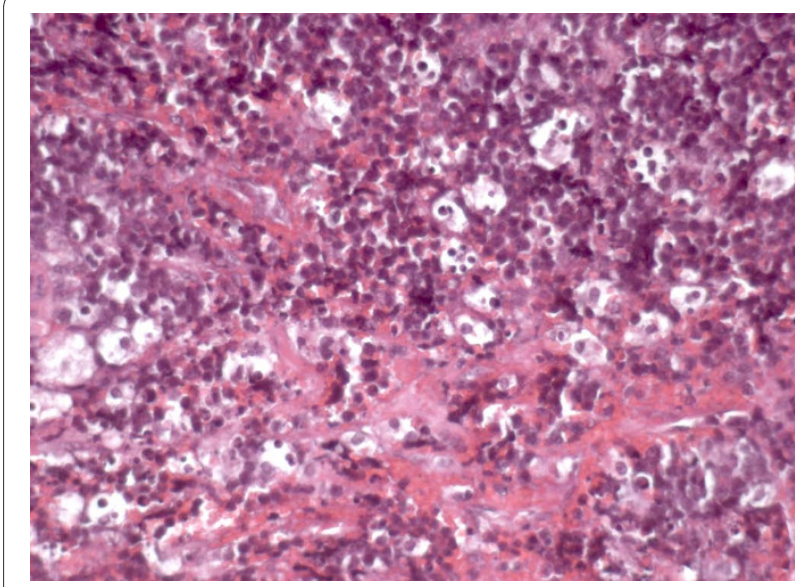

Figure 1 Hematoxylin and eosin stainig: Hematoxylin and eosin section showing monomorphic population of neoplastic lymphoid cells and large pale macrophages forming the "stars" in the "starry sky" typical of Burkitt Lymphoma (HE 20x).

The patient was treated according to the Italian Association of Pediatric Hematology Oncology (AIEOP) protocol which includes dexamethasone, ifosfamide, methotrexate, cytarabine, etoposide phosphate, vincristine, cyclophosphamide, daunomycin and intrathecal administration of prednisolone, cytarabine and methotrexate. He received four courses of chemotherapy resulting in a rapid tumor regression followed by the complete remission (CR) after the fourth course. The neutropenic period lasted from day 7 to day 12 after treatment without further chemotherapic toxicity. During this period he received antibacterial, antiviral and antifungal prophylaxis as well as blood transfusions and G-CSF support. In parallel with chemotherapy, highly active antiretroviral therapy (HAART) based on four drugs (lopinavir/ritonavir + abacavir/lamivudina) was started.

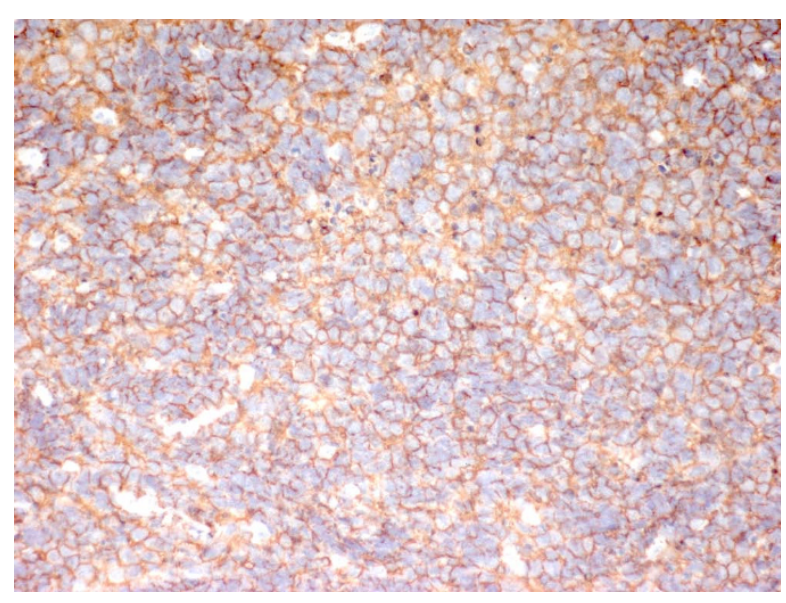

Figure 2 Immunohistochemical staining: Immunohistochemistry showing tumor cells are positive for CD20 (CD20 20x)

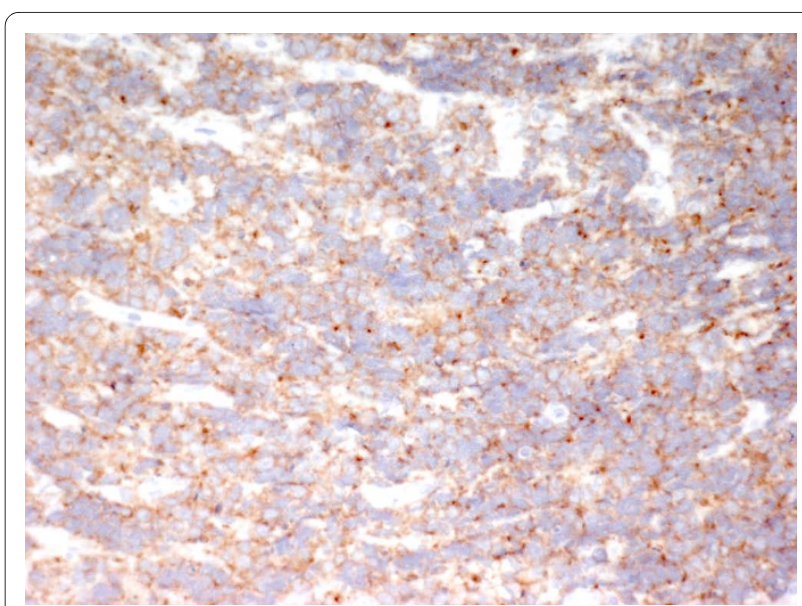

Figure 3 Immunohistochemical staining: Immunohistochemistry showing tumor cells are positive for CD10 (CD10 20X)

The patient, over the last 3 years, has been regularly followed-up by the HIV Unit of our Hospital. Blood count, LDH, EBV, HIV viral load and CD4 cell counts were detected every 3 months. Abdominal and cervical ultrasound were performed at regular intervals of six months. Viral load resulted undetectable (number of copies <50/ $\mathrm{ml}$ ) after 10 months of HAART initiation. The patient remains in good health condition maintaining CR over the last 3 years of follow-up. HIV plasma viral load is still undetectable with good immune reconstitution (CD4 count $603 / \mathrm{mm} 3$ or $24,5 \%$ ) [Table 1 ].

\section{Discussion}

We report a case of vertical HIV infection presenting with atypical features because of the timing of presentation and the long term period free of the characteristic early signs and symptoms of AIDS.

Human immunodeficiency virus (HIV)-infected children have an increased risk of developing cancer, particularly in the later stages of acquired immune deficiency syndrome (AIDS) and AIDS-related non-Hodgkin's lymphomas are one of the most common AIDS-defining malignancies [1].

This seems to be related to multiple factors, including the transforming properties of the human retrovirus itself, the duration and degree of immunodeficiency and viral exposure [2], the immune activation leading to B cell proliferation and further infections with other lymph tropic viruses such EBV $[3,4]$.

Without Antiretroviral Treatment (ART), progression of HIV infection in vertically infected children is most rapid than in adults and about one-fifth progress to serious clinical illness or die before one year of age [5]. In fact, in HIV-1- infected non treated children the rates of progression to AIDS are $17 \%$ at 1 year of age and $35 \%$ at 5 
years of age [6-8]. For this reason, BL is a common comorbidity of HIV infection particularly in developing countries, where people do not have access to antiretroviral drugs [9], but rarely represents the initial clinical manifestation of vertical HIV infection in adolescent in Western Europe. Indeed, the introduction of protocols to prevent mother-to-child transmission and efficacious regimens of early antiretroviral treatment have resulted in a substantial and dramatic decrease in AIDS-related opportunistic infections and cancers in both adults and children [1,4,10-12].

However, despite this progress, recent data show as HIV infection itself represents a major risk factor for developing cancers [13] especially in young adults, a new phenomena made possible by the improved survival followed by HAART use and the low adherence to treatment reported during this age [14]. Within HIV-related tumors, Non Hodgkin's Lymphomas remain the most frequent malignancies of children with AIDS [15,16]. In the developed countries NHL accounts for 65\%-83\% of AIDS-related malignancies, and BL rates about $40 \%$ of HIV-related NHL in children $[17,18]$. Hence, BL rarely represents the first sign of HIV infection in childhood whose HIV exposure status is not known [19]. Interestingly in this case, although the patient vertically acquired HIV infection, he had an asymptomatic neonatal period and childhood, with normal growth and development, up to 16 years old. As previously discussed this silent pathological history led to misdiagnose the vertical HIV infection. However, the presence of marked hypergammaglobulinemia associated with severe immunodeficiency and the diagnosis of BL allowed us to suspect and subsequently diagnose HIV infection and start an adequate treatment.

Before the widespread use of HAART, in patients with $\mathrm{BL}$ and HIV, the chemotherapy was less aggressive than in non-HIV-infected patients, with parallel corresponding poorer results. This approach is presently abandoned, since recent cumulative evidences have showed comparable results with full intensive chemotherapy between HIV infected and non-infected individuals in terms of toxicity effects and survival [20]. Indeed, although the patient hereby described received high-dose polychemotherapy, no serious toxic effects neither life-threatening infections were recorded.

Patients who developed NHL but who did not undergo HAART had better survival, particularly when compared with patients who developed NHL after HAART initiation [21-23]. Thus, starting antiretroviral therapy in addition to chemotherapy after the diagnosis of NHL may represent an effective salvage therapy even for those patients who have NHL as their AIDS-defining event, as in this case [22,23].

\section{Conclusion}

This case illustrates a HIV-associated BL, initially misdiagnosed as a common mononucleosis syndrome. It represents an atypical presentation of vertical HIV infection because of the total absence of characteristic early signs and symptoms of AIDS.

This case highlights the increased risk to develop NHL of young HIV positive individuals. Indeed, despite the introduction of antiretroviral therapy several studies report a lesser decrease in incidence rates of NHL compared with others type of cancers (i.e. Kaposi's sarcoma) in this population $[13,24]$. Recent data show as immunodeficiency and HIV viremia are major risk factors for developing cancers $[2,13,24]$ especially in young adults. In this optic, lower adherence to treatment reported during this age [14] might represent an emerging problem. Thus, access to NLH screening programmes should be regularly offered to all HIV-positive adolescents and young adults [24].

\section{Consent}

Written informed consent was obtained from the patient for publication of this case report and any accompanying images.

\section{Competing interests \\ The authors declare that they have no competing interests.}

\section{Authors' contributions}

VS: made substantial contributions to conception and design of case report. AA: made contributions to acquisition and interpretation of data.

NM: has been involved in drafting the manuscript or revising it critically for important intellectual content.

HTC: has been involved in drafting the manuscript or revising it critically for important intellectual content.

GP: has given final approval of the version to be published.

SB: made substantial contributions to clinical management of the patient and has given final approval of the version to be published

RDV: has been involved in acquisition, analysis and interpretation of histological data.

PP: made substantial contributions to clinical management of the patient and has given final approval of the version to be published

All authors read and approved the final manuscript.

\section{Acknowledgements}

Prof. Paolo Rossi for critically review in the manuscript.

\section{Author Details}

'DPUO, University Department of Pediatrics- Children's Hospital Bambino Gesù, Rome, Italy, 2Unit of Anatomical Pathology- Children's Hospital Bambino Gesù, Rome, Italy and 3Unit of Haematology- Children's Hospital Bambino Gesù, Rome, Italy

Received: 25 February 2010 Accepted: 23 April 2010 Published: 23 April 2010

\section{References}

1. Cheung MC, Pantanowitz L, Dezube BJ: AIDS-related malignancies: emerging challenges in the era of highly active antiretroviral therapy. Oncologist 2005, 10:412-26.

2. Zoufaly A, Stellbrink HJ, Heiden MA, Kollan C, Hoffmann C, van Lunzen J, Hamouda O: Cumulative HIV Viremia during Highly Active 
Antiretroviral Therapy Is a Strong Predictor of AIDS-Related Lymphoma. The Journal of Infectious Diseases 2009, 200:79-87.

3. Preciado MV, Fallo A, Chabay P: Epstein Barr Virus associated Lymphoma in HIV infected children. Pathol Res Pract 2002, 198:327-32.

4. Grogg KL, Miller RF, Dogan A: HIV infection and lymphoma. J Clin Pathol 2007, 60:1365-72.

5. Prendergast A, Tudor-Williams G, Jeena P, Burchett S, Goulder P. International perspectives, progress, and future challenges of paediatric HIV infection. Lancet 2007, 370:68-80

6. The European Collaborative Study: Natural history of vertically acquired human immunodeficiency virus-1 infection. Pediatrics 1994 94:815-819.

7. Bamii M, Thea DM, Weedon J, Krasinski K, Matheson PB, Thomas P, Lambert G, Abrams EJ, Steketee R, Heagarty M: Prospective study of human immunodeficiency virus 1-related disease among 512 infants born to infected women in New York City. Pediatr Infect Dis J 1996, 15:891-898

8. Lepage P, Spira R, Kalibala S, Pillay K, Giaquinto C, Castetbon K, Osborne C, Courpotin C, Dabis F: Care of human immunodeficiency virus-infected children in developing countries: report of a workshop for clinical research. Pediatr Infect Dis J 1998, 17:581-586.

9. Koenig SP, Kuritzkes DR, Hirsch MS, Léandre F, Mukherjee JS, Farmer PE, del Rio C: Monitoring HIV treatment in developing countries. BMJ 2006, 332:602-4.

10. McClain KL, Joshi V, Murphy SB: Cancers in children with HIV infection. Hematol Oncol Clin North Am 1996, 10:1189-201.

11. Palella FJ Jr, Delaney KM, Moorman AC, Loveless MO, Fuhrer J, Satten GA, Aschman DJ, Holmberg SD: Declining morbidity and mortality among patients with advanced human immunodeficiency virus infection. HIV Outpatient Study Investigators. N Eng/ J Med 1998, 338:853-860.

12. D'Arminio Monforte A, Sabin CA, Phillips A, Sterne J, May M, Justice A Dabis F, Grabar S, Ledergerber B, Gill J, Reiss P, Egger M: The changing incidence of AIDS events in patients receiving highly active antiretroviral therapy. Arch Intern Med 2005, 165:416-423.

13. Polesel J, Franceschi S, Suligoi B, Crocetti E, Falcini F, Guzzinati S, Vercelli M, Zanetti R, Tagliabue G, Russo A, Luminari S, Stracci F, De Lisi V, Ferretti S, Mangone L, Budroni M, Limina RM, Piffer S, Serraino D, Bellù F, Giacomin A, Donato A, Madeddu A, Vitarelli S, Fusco M, Tessandori R, Tumino R, Piselli $P$, Dal Maso L: Cancer incidence in people with AIDS in Italy. Int J Cancer 2010, 000:000-000.

14. Rudy BJ, Murphy DA, Harris DR, Muenz L, Ellen J, Adolescent Trials Network for HIV/AIDS Interventions: Patient-related risks for nonadherence to antiretroviral therapy among HIV-infected youth in the United States: a study of prevalence and interactions. AIDS Patient Care STDS 2009, 23(3):185-94

15. Engels EA, Pfeiffer RM, Goedert JJ, Virgo P, McNeel TS, Scoppa SM, Biggar RJ, for the HIV/AIDS Cancer Match Study: Trends in cancer risk among people with AIDS in the United States 1980-2002. AIDS 2006, 20:1645-54

16. International Collaboration on HIV and Cancer: Highly active antiretroviral therapy and incidence of cancer in human immunodeficiency virus-infected adults. J Natl Cancer Inst 2000 92:1823-30

17. Muller BU: HIV-associated malignancies in children. AIDS Patient Care STDS 1999, 13:527-533.

18. Fedorova A, Mlyavaya T, Alexeichik A, Busel T, Petrovich I, Aleinikova O: Successful treatment of the HIV-associated Burkitt lymphoma in a three-year-old child. Pediatr Blood Cancer 2006, 47(1):92-3.

19. Stefan DC, Van Toorn R, Andronikou S: Spinal compression due to Burkitt lymphoma in a newly diagnosed HIV-infected child. J Pediatr Hematol Oncol 2009, 31(4):252-5.

20. Mounier N, Spina M, Gisselbrecht C: Modern management of nonHodgkin lymphoma in HIV-infected patients. Br J Haematol 2007, 136(5):685-98. Epub 2006 Dec 1

21. Caselli D, Klersy C, de Martino M, Gabiano C, Galli L, Tovo PA, Aricò M: Human immunodeficiency virus-related cancer in children: Incidence and treatment outcome--Report of the Italian Register. J Clin Oncol 2000, 18:3854-3861

22. Kenkre VP, Stock W: Burkitt lymphoma/leukemia: improving prognosis. Clin Lymphoma Myeloma 2009, 9(Suppl 3):S231-8.

23. Collaboration of Observational HIV Epidemiological Research Europe (COHERE) study group, Bohlius J, Schmidlin K, Costagliola D, Fätkenheuer
G, May M, Caro Murillo AM, Mocroft A, Bonnet F, Clifford G, Touloumi G, Miro JM, Chene G, Lundgren J, Egger M: Prognosis of HIV-associated non-Hodgkin lymphoma in patients starting combination antiretroviral therapy. AIDS 2009, 23(15):2029-37.

24. Guiguet M, Boué F, Cadranel J, Lang JM, Rosenthal E, Costagliola D, on behalf of the Clinical Epidemiology Group of the FHDH-ANRS CO4 cohort: Effect of immunodeficiency, HIV viral load, and antiretroviral therapy on the risk of individual malignancies (FHDH-ANRS CO4): a prospective cohort study. Lancet Oncol 2009, 10:1152-59.

doi: $10.1186 / 1824-7288-36-34$

Cite this article as: Santilli et al., Burkitt's lymphoma mimicking EBV disease as first sign of vertical HIV infection in an adolescent Italian Journal of Pediatrics 2010, 36:34

\section{Submit your next manuscript to BioMed Central and take full advantage of:}

- Convenient online submission

- Thorough peer review

- No space constraints or color figure charges

- Immediate publication on acceptance

- Inclusion in PubMed, CAS, Scopus and Google Scholar

- Research which is freely available for redistribution
C Biomed Central 